\title{
Regulation of Stem Cell Differentiation by Histone Methyltransferases and Demethylases
}

\author{
D. Pasini, A.P. Bracken,* K. Agger, J. Christensen, \\ K. HaNSEN, P.A.C. Cloos, and K. HeLIN \\ Biotech Research and Innovation Centre (BRIC) and Centre for Epigenetics, \\ University of Copenhagen, Ole Maaløes Vej 5, Copenhagen, Denmark
}

\begin{abstract}
The generation of different cell types from stem cells containing identical genetic information and their organization into tissues and organs during development is a highly complex process that requires defined transcriptional programs. Maintenance of such programs is epigenetically regulated and the factors involved in these processes are often essential for development. The activities required for cell-fate decisions are frequently deregulated in human tumors, and the elucidation of the molecular mechanisms that regulate these processes is therefore important for understanding both developmental processes and tumorigenesis.
\end{abstract}

Polycomb group (PcG) proteins control the expression of genes important for cell-fate decisions and are essential for embryogenesis, cell proliferation, and stem cell self-renewal. The PcG proteins form multiprotein complexes, called Polycomb repressive complexes (PRCs). The PRC2 complex contains the PcG proteins EZH2, SUZ12, and EED and is believed to repress transcription through methylation of lysine $(\mathrm{K})$ 27 of histone $\mathrm{H} 3$ (H3). All three PcG components of the PRC2 complex are essential for the activity of the complex and they are required for early mouse embryogenesis.

In this chapter, we present some of the recent findings regarding the role of PcG proteins and lysine demethylases in embryonic stem cell differentiation, with the perspective of discussing models by which histone methyltransferases and demethylases are involved in regulating transcription during stem cell maintenance and cellular differentiation.

The development of a whole organism is a complex process that requires the precise regulation of transcription. Such regulation is essential to allow correct cellular commitment during development. Embryonic stem (ES) cells are pluripotent cells derived from the inner cell mass (ICM) of preimplantation embryos, which can be indefinitely maintained in tissue culture and differentiated into many different cell types (Keller 2005). Thus, ES cells are powerful as a tool, not only to generate genetic mouse models, but also to study the molecular mechanisms that regulate pluripotency and differentiation. Furthermore, loss of cellular commitment is a common feature of human cancers (Hanahan and Weinberg 2000), and the delineation of the mechanisms involved in regulating differentiation programs therefore becomes important for understanding the development of cancer.

*Present address: Smurfit Institute of Genetics, Trinity College, Dublin 2, Ireland.

\section{THE POLYCOMB GROUP PROTEINS}

The first PcG protein was discovered in Drosophila 60 years ago (Kennison 1995). The PcGs were defined as factors that, when mutated, give phenotypes similar to those of mutations in homeotic genes. This effect is counteracted by mutations in the Trithorax group (TrxG) proteins, which compete with the PcG proteins for binding to the same DNA elements (Ringrose and Paro 2004). In general, $\mathrm{PcG}$ proteins act as transcriptional repressors and are required for maintaining the repressive state of homeotic genes during fly development. The expression of homeotic genes is set up by the activity of segmentation proteins. This occurs transiently in early development, and the PcG and TrxG proteins maintain their repression or activation, respectively, during later development (Ringrose and Paro 2004). However, other results have shown that PcG proteins are expressed and are associated with homeotic genes earlier than the segmentation proteins (Orlando et al. 1998), suggesting that the mechanism by which fly development is regulated is more complex than current models indicate.

PcG proteins are highly conserved during evolution, and they execute their functions in multiprotein complexes. The best-characterized PcG complexes are the Polycomb repressive complexes 1 and 2 (PRC1 and PRC2) (Francis and Kingston 2001; Simon and Tamkun 2002; Pasini et al. 2004a). Orthologs of PRC1 members can be found in Drosophila to mammals, whereas orthologs of the PRC2 complex are also found in nematodes and plants (Brock and Fisher 2005). The PRC1 complex contains several different subunits, and its composition can change in different cell types (Pasini et al. 2007; Puschendorf et al. 2008). The four Drosophila proteins $\mathrm{Pc}, \mathrm{Psc}, \mathrm{Ph}$, and dRING1 define the PRC1 core (Francis et al. 2001). The PRC1 complex contains two different enzymatic activities: Drosophila RING1 (RING1A and RING1B in mammals) catalyzes the ubiquitylation of histone $\mathrm{H} 2 \mathrm{~A}$ and its loss of function leads to 
global loss of H2A K119 ubiquitylation in vivo (de Napoles et al. 2004; Wang et al. 2004; Cao et al. 2005; Stock et al. 2007; van der Stoop et al. 2008). Mammalian CBX4 (one of five homologs of Drosophila Pc) is an E3 SUMO ligase that has been shown to catalyze the sumoylation of the transcriptional repressor CtBP (Kagey et al. 2003, 2005). In vitro, the PRC1 complex retains the ability to bind in trans to nucleosomal arrays in a sequenceindependent manner (Lavigne et al. 2004) and to induce compaction of nucleosomes (Francis et al. 2004). These different activities of PRC1 suggest various mechanisms by which PRC1 inhibits transcription.

The PRC2 complex is smaller than PRC1, and it is composed of the three PcG proteins EZH2, EED, and SUZ12 and the histone-binding proteins RbAp48/46. Through its catalytic subunit EZH2, the PRC2 complex preferentially methylates (me) K27 of histone $\mathrm{H} 3$ in vitro (Cao et al. 2002; Czermin et al. 2002; Kuzmichev et al. 2002; Müller et al. 2002). However, different groups have reported that PRC2 also can methylate histone $\mathrm{H} 3 \mathrm{~K} 9$ and histone H1K26 in vitro (Czermin et al. 2002; Kuzmichev et al. 2002, 2004; Erhardt et al. 2003; Su et al. 2003; Pasini et al. 2004b), but so far, genetic models only provide support for the involvement of EZH2 in catalyzing dimethylation and trimethylation of histone H3K27 in vivo (Cao and Zhang 2004; Pasini et al. 2007; Puschendorf et al. 2008; Riising et al. 2008). The activity of the PRC2 complex is required for the association of PRC1 to target genes (Cao et al. 2005; Pasini et al. 2007). This might involve a mechanism by which PRC1 is recruited to the $\mathrm{H} 3 \mathrm{~K} 27 \mathrm{me} 3$ mark through direct binding of the chromodomain containing the CBX component of the PRC1 complex (Cao et al. 2002; Kuzmichev et al. 2002). Therefore, most current models of PcG-mediated transcriptional repression involve, first, the recruitment of the PRC2 complex to target genes, leading to methylation of $\mathrm{H} 3 \mathrm{~K} 27$ and the subsequent recruitment of PRC1 through binding to $\mathrm{H} 3 \mathrm{~K} 27 \mathrm{me} 3$. PRC1 recruitment results in H2AK119 ubiquitylation (ubq) and chromatin compaction, resulting in a more stably transcriptional repressive state. Despite the fact that this model requires further experimental verification, the finding that PRC complexes share most if not all target genes in different cell types (Boyer et al. 2006; Bracken et al. 2006; Lee et al. 2006) strongly suggests that the two complexes have coordinated functions and supports the repressive model presented in Figure 1.

The components of the PRC2 complex are essential for mouse embryonic development. Knockout embryos for Ezh2, Eed, and Suz12 die during early postimplantation stages during gastrulation (O'Carroll et al. 2001; Pasini et al. 2004b; Montgomery et al. 2005). The generation of mouse ES cell lines from Eed and Suz12 knockout preimplantation embryos has shown that PRC2 activity is dispensable for the stem cell self-renewal but that Eed and Suz12 knockout ES cells have an increased expression of differentiation-specific genes and a tendency to differentiate (Montgomery et al. 2005; Boyer et al. 2006; Lee et al. 2006; Pasini et al. 2007; Chamberlain et al. 2008). Attempts to derive Ezh2 knockout ES cell lines were reported to be unsuccessful, suggesting that EZH2 is

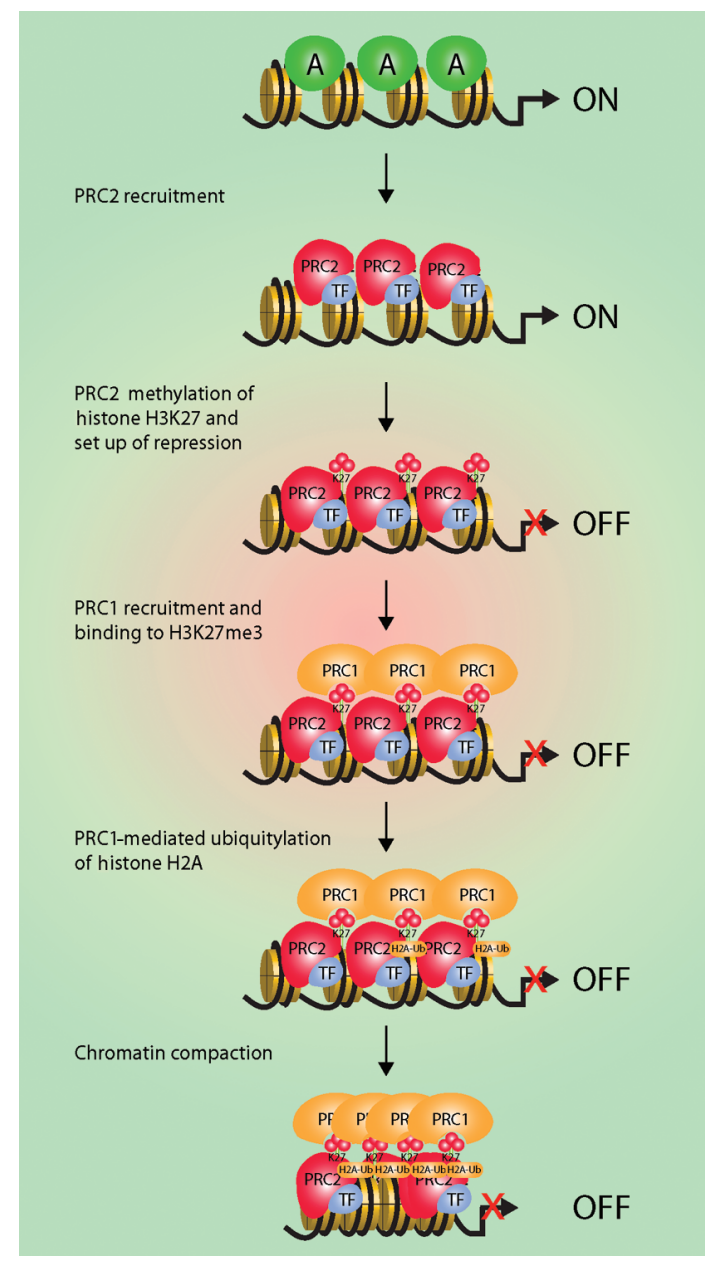

Figure 1. Proposed model for the mechanism by which Polycomb group proteins regulate their target genes. First, the PRC2 complex is recruited by ill-defined transcription factors, leading to the methylation of histone H3K27. This methylation results in the recruitment of the PRC1 complex through the binding to methylated K27. Subsequently, the RING1B protein of the PRC1 complex catalyzes the ubiquitylation of histone H2A K119, which may lead to chromatin compaction.

required for ES cell self-renewal (O'Carroll et al. 2001). The fact that both Eed and Suz 12 knockout ES cells globally lose H3K27me2/3 might suggest that Ezh2 has PRC2-independent functions that do not involve H3K27 methylation.

Interestingly, the analyses of ES cell differentiation of Suz12 and Eed knockout ES cells have shown that the proteins are required for proper differentiation. The lack of differentiation correlates with failure to activate lineage-specific genes and to repress genes involved in stem cell self-renewal (Pasini et al. 2007; Chamberlain et al. 2008). These results are in agreement with the early developmental defects in PRC2 knockout embryos and show that the PRC2 proteins are critical for cell-fate determination during development.

Differently from PRC2, mice with mutations in genes of the PRC1 complex have less pronounced embryonic defects. For example, Bmil (Psc in Drosophila) knockout 
mice die at birth with pronounced neural and hematopoietic defects (van der Lugt et al. 1994). This result could appear at odds with the proposed coordinated regulation of PRC2 and PRC1 repressive activities, but it is most likely a result of functional redundancy between the PRC1 subunits (Bmil has, for instance, five homologs in mice). In agreement with this, the inactivation of Rnf2 (Ring1B, dRING1 in Drosophila), which has only one homolog (Ring1a), leads to embryonic lethality in early postimplantation stages in mice, demonstrating that lack of PRC1 enzymatic activity is indeed essential for embryonic development (Voncken et al. 2003). Although Rnf2 knockout ES cells show global loss of H2A ubiquitylation and have an increased expression of differentiation-specific genes, they can be established, similarly to ES cells devoid of PRC2 activity (de Napoles et al. 2004; Stock et al. 2007; Endoh et al. 2008; van der Stoop et al. 2008). Taken together, these data imply a crucial role for Rnf 2 in PRC1 function and support the functional overlap between PRC1 and PRC2.

\section{PCG TARGET GENES}

Many aspects of PcG transcriptional regulation are still not fully understood. This includes the signaling pathways that control PRC2 activity, factors that mediate PcG recruitment to target genes, molecular mechanisms by which PcG inhibits transcription, and downstream pathways regulated by the PcG proteins. The identification of direct target genes of the PcG proteins within the last couple of years has significantly extended our knowledge regarding the downstream pathways regulated by the PcG proteins and, at the same time, has provided us with the tools to unravel the mechanism by which PcG proteins regulate transcription. Genome-wide location analyses using chromatin immunoprecipitation (ChIP) of PcG proteins and $\mathrm{H} 3 \mathrm{~K} 27 \mathrm{me} 3$ in different cells lines, including mouse and human ES cells, have led to the following observations:

1. PcG and H3K27me3 are mainly associated with transcriptional start sites (TSS) of genes (Lee et al. 2006). In contrast to this, Drosophila PcG proteins are also found to be associated with Polycomb responsive elements (PREs) located several kilobases from the TSS (Ringrose and Paro 2004). This may suggest that the mechanism by which PcG proteins control transcription is not conserved between Drosophila and mammals.

2. The PcG proteins bind directly to the promoters of a large number of important regulators controlling cellfate decisions during development in both human and mouse ES cells as well as in human embryonic fibroblasts (hEF) (Boyer et al. 2006; Bracken et al. 2006; Lee et al. 2006). The studies have shown that the PcGs are associated with the TSS of entire gene families, including homeobox, Gata, Pax, Sox, Wnt, Fgf, and T-box genes. These findings suggest a model by which the PcG proteins are displaced from their target genes when cells differentiate and that this displacement is required for the correct expression of lineagespecific genes.
3. PcG target genes are not fully conserved in different cell types. Comparison between cell lines such as ES, mouse embryonic fibroblast (MEF), $\mathrm{C} 2 \mathrm{C} 12$ myoblasts, and hEF has shown that a proportion of PcG target genes are not conserved. Perhaps, not so surprisingly, PcG target genes show the largest degree of difference between normal and cancer cells (Bernstein et al. 2006a; Boyer et al. 2006; Bracken et al. 2006; Lee et al. 2006; Squazzo et al. 2006; Mikkelsen et al. 2007; Mohn et al. 2008). This difference could be partly flawed if the cancer cells are not compared to their normal counterparts, i.e., the cell of origin for the tumor cells. However, more intriguingly, the observed differences could be a result of the transformation process. Interestingly, despite the low degree of overlap between normal and tumor cells, PRC2 activity is essential for the proliferation of all cells tested so far, and it does not exclusively depend on the ability of $\mathrm{PcG}$ proteins to repress the INK4A$A R F$ locus (Bracken et al. 2003; Pasini et al. 2004b).

4. Different models describing how the PcG proteins regulate their target genes during differentiation have been proposed. We and other investigators have shown that PcG proteins are displaced from promoters when ES cells undergo differentiation. Moreover, the PcGs are also actively recruited to a substantial number of genes during differentiation (Bracken et al. 2006; Pasini et al. 2007; Mohn et al. 2008). Surprisingly, we have also found that the PcG proteins accumulate on some genes, even though they are activated, during differentiation (Pasini et al. 2007). Taking into consideration that ES cells do not differentiate synchronously, these results could suggest either that PcG activity is required for the transcriptional activation of some target genes or that, in some cases, the binding of the PcG proteins does not exclude transcription and may instead predispose the target genes for repression in later differentiation stages. Some support for the first hypothesis is provided by the fact that the activation of these genes does not occur in Suz12 knockout ES cells (Pasini et al. 2007); however, this may also be due to the lack of proper differentiation of these cells. The second hypothesis is supported by the fact that transcribed genes such as NEUROG2 and OLIG2 are bound by PcGs and enriched for H3K27me3 in NT2 embryonic teratocarcinoma cells (Bracken et al. 2006).

We have summarized the different models for how the $\mathrm{PcG}$ proteins regulate transcription in Figure 2. Whereas solid evidence supports both the derepression and the recruitment models, further studies using differentiation systems with highly pure cellular populations combined with ChIP-re-ChIP (reverse ChIP) approaches are required to validate the activation model.

\section{DOWNSTREAM FROM THE PCG PROTEINS}

As previously mentioned, PcGs associate with the promoters of several genes whose activities are required for cell-fate determinations during development (Boyer et al. 

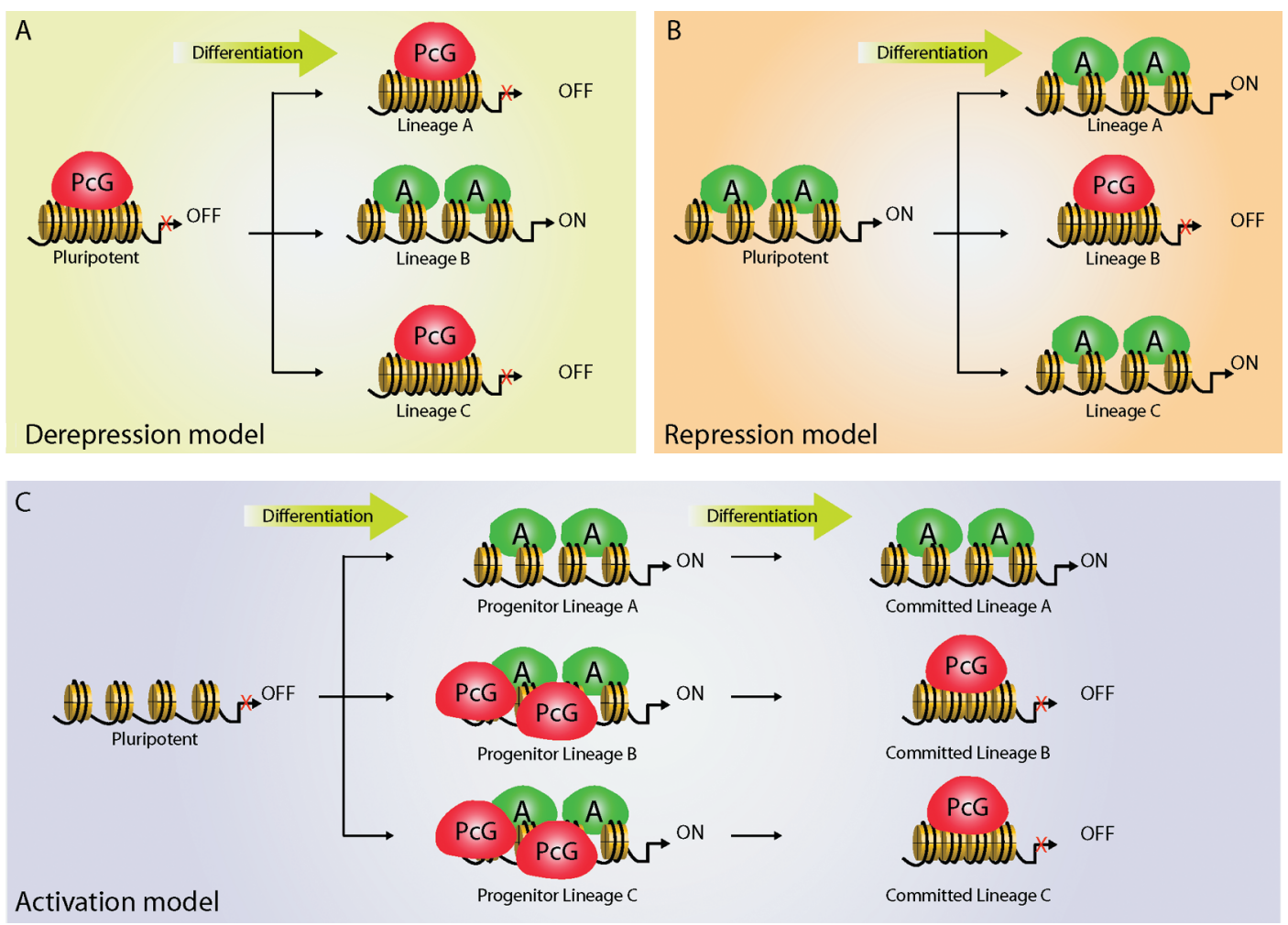

Figure 2. Model for the potential mechanisms by which the PcG proteins regulate transcription during differentiation. (A) Schematic representation of the derepression model, suggesting that displacement of PcG-binding contributes to the lineage-specific expression of target genes. $(B)$ Schematic representation of the repression model, suggesting that PcGs can be actively recruited to the promoters of lineage-specific genes during differentiation. (C) Schematic representation of the activation model, showing that PcGs can be recruited to specific target genes that undergo transcriptional activation during differentiation. The model further highlights the fact that $\mathrm{PcG}$ recruitment may predispose these target genes for repression in later differentiation stages.

2006; Bracken et al. 2006; Lee et al. 2006). Among these, some deserve particular considerations.

The PcG proteins control expression of the HOX genes. They are bound to all four $H O X$ gene clusters in ES cells (Boyer et al. 2006; Lee et al. 2006), and the use of tiling arrays in hES cells demonstrated that PcGs and H3K27me3 spread throughout the entire cluster (Lee et al. 2006). Interestingly, similar experiments in committed hEF cells showed that the $3^{\prime}$ end of all clusters lose PcG association and $\mathrm{H} 3 \mathrm{~K} 27 \mathrm{me} 3$ (Bracken et al. 2006). Similar to their requirement in fly development, the HOX proteins are indispensable for mammalian development. Their spatial and temporal expression is essential and requires a tight regulation throughout development (Wellik 2007). Several results have suggested that PcGs are required for maintaining all $H O X$ genes silenced in pluripotent cells and that differential PcG dissociation from $H O X$ genes may be required for the coordinated regulation of $H O X$ expression during development (Cao et al. 2005; Boyer et al. 2006; Bracken et al. 2006).

Another group of transcription factors regulated by the PcG proteins are the GATA factors. These transcription factors have different roles in development, and whereas GATA1, -2 , and -3 are essential in hematopoiesis (Bresnick et al. 2005), GATA4, -5, and -6 seem to be required for myocardial development (Laverriere et al.
1994). Interestingly, the loss of PcGs in ES cells results in increased levels of GATA3, -4, and -6 (Boyer et al. 2006). This result further suggests an important role for PcG proteins in GATA repression, and consistent with this, the tissue-specific inactivation of Ezh2 leads to B- and T-cell developmental defects (Su et al. 2003, 2005).

$\mathrm{PcG}$ proteins directly associate with the promoters of several members of other transcription factor families such as the SRY box (SOX), T-box (TBX), forkhead box (FOX), and paired box (PAX) genes that have essential roles in regulating different developmental processes (Carlsson and Mahlapuu 2002; Plageman and Yutzey 2005; Kiefer 2007; Lang et al. 2007). Moreover, PcGs also associate with the promoters of gene families involved in different signaling pathways, including genes involved in transforming growth factor- $\beta$ (TGF- $\beta$ ), WNT, and fibroblast growth factor (FGF) signaling. These signaling pathways regulate development by acting on cell-fate, patterning, and mitogenic signals (Kitisin et al. 2007; Cohen et al. 2008; Hayward et al. 2008; Itoh and Ornitz 2008).

Finally, our studies have demonstrated that PcG proteins directly bind and repress the INK4A-ARF tumor suppressor locus (Bracken et al. 2007). This locus codes for the expression of two negative regulators of the cell division cycle: $\mathrm{p} 16^{\mathrm{INK} 4 \mathrm{~A}}$ and $\mathrm{p} 14^{\mathrm{ARF}}$ ( $\mathrm{p} 19^{\mathrm{ARF}}$ in mouse). 
p $16^{\mathrm{INK} 4 \mathrm{~A}}$ inhibits CDK4/CDK6 activity, and therefore phosphorylation of members of the retinoblastoma protein $\mathrm{pRB}$ family, whereas $\mathrm{p} 14^{\mathrm{ARF}}$ inhibits the activity of MDM2, thereby leading to the accumulation of p53. Elevated levels of both $\mathrm{p} 16^{\mathrm{INK} 4 \mathrm{~A}}$ and $\mathrm{p} 14^{\mathrm{ARF}}$ expression lead to cell cycle arrest (Sherr 1998; Lowe and Sherr 2003). Importantly, activation of $\mathrm{p} 16^{\mathrm{INK} 4 \mathrm{~A}}$ and $\mathrm{p} 14^{\mathrm{ARF}}$ expression as a result of oncogene activation, oxidative stress, or other types of stress signals correlates with the displacement of the PcG proteins and decreased levels of $\mathrm{H} 3 \mathrm{~K} 27 \mathrm{me} 3$ from the INK4A-ARF locus (Bracken et al. 2007). Consistent with a causal role of $P c G$ proteins in the regulation of the locus, both genetic inactivation and RNA interference (RNAi)-based depletion of different PcG members induce premature senescence, whereas overexpression of $\mathrm{PcG}$ proteins such as BMI1, $\mathrm{EZH} 2, \mathrm{CBX} 7$, and $\mathrm{CBX} 8$ prevents stressed-induced senescence in an INK4A-ARF-dependent manner (Jacobs et al. 1999; Bracken et al. 2003, 2007; Gil et al. 2004; Dietrich et al. 2007). Importantly, the regulation of cell proliferation through binding to the INK4A-ARF locus is an essential feature of PcG proteins in mammalian cells, as first illustrated by the remarkable observation that several phenotypes of $B m i 1^{-1}$ knockout mice are rescued by con- comitant deletion of the Ink4a-Arf locus (Jacobs et al. 1999; Bruggeman et al. 2005; Molofsky et al. 2005). These results also show that PcG proteins regulate embryonic development and normal differentiation by controlling both cell proliferation and the expression of a large number of genes involved in cell-fate decisions.

\section{MECHANISMS FOR PCG TRANSCRIPTIONAL REGULATION}

Although understanding of the downstream regulatory pathways regulated by PcG proteins is becoming clearer, two other aspects of PcG regulation are still poorly understood. First, the mechanisms by which PcGs are recruited to their target genes in mammalian cells remain elusive, and second, it is not fully understood how the PcG proteins repress transcription.

In Drosophila, the transcription factors Gaga, Psq, Zeste, Pho, and Pho-like (PhoL) mediate PcG recruitment to PREs (Brown et al. 2003). A PRE consists of multiple binding sites for these transcription factors, and it is believed that a PRE is defined by a combination of these binding sites. An algorithm to predict Drosophila PREs has been designed and has successfully predicted novel PREs (Ringrose et al. 2003; Ringrose and Paro 2007). This algorithm cannot predict any putative PREs from mammalian genomes and, together with the ChIP-chip data (Lee et al. 2006; Mikkelsen et al. 2007), suggests that these elements are not conserved.

Homologs for the transcription factors binding the Drosophila PREs are, with the exception of Pho, not found in mammals. Pho is homologous to the mammalian transcription factor Yin Yang 1 (YY1) (Brown et al. 1998). Consistent with this, it was shown that Yy1 and Ezh2 interact and colocalize to the $M h c 2 b$ promoter in undifferentiated C2C12 myoblasts (Caretti et al. 2004).
The fact that YY1 has not been reported to copurify with the PRC complexes could suggest that the association between YY1 and the PRCs is not stable (Cao et al. 2002; Czermin et al. 2002; Kuzmichev et al. 2002; Müller et al. 2002). Importantly, Yyl knockout mice are not viable and are embryonic-lethal in early postimplantation stages, similar to Ezh2, Eed, Suz12, and Rnf2 knockout embryos (Donohoe et al. 1999). This result supports the possibility of a functional link between Yy1 and PRC complexes. Thus, it appears that the identification of target genes for YY1 in different cell types by genome-wide techniques is important for understanding the extent of overlap between YY1 and PcG proteins.

As described above, recent ChIP-chip and ChIPsequencing (ChIP-seq) studies have led to the identification of PcG-associated DNA sequences (Boyer et al. 2006; Bracken et al. 2006; Lee et al. 2006; Mikkelsen et al. 2007). On the basis of these studies, it should be possible to identify DNA sequences or elements that function as PREs in mammalian cells. However, so far, no studies have been published in which a mammalian PRE has been identified. This could suggest that PREs do not exist or that there are many different PREs containing DNA-binding sites for a number of different transcription factors. The existence of a large number of PREs would allow the PcGs to differentially regulate gene expression depending on cell-type specification. Supporting a role for specific transcription factors in the regulation of $\mathrm{PcG}$ target genes is the recent demonstration that the transcription factor Snaill recruits the PRC2 complex to the E-cadherin promoter to repress its expression in the mesoderm of developing mouse embryos (Herranz et al. 2008). Consistent with this, PcG target genes diverge when comparing different cell types (Squazzo et al. 2006; Mohn et al. 2008).

How do PcGs regulate transcription? As we have discussed above, PcG binding mainly correlates with transcriptional silencing (Boyer et al. 2006; Lee et al. 2006; Mikkelsen et al. 2007). Forced recruitment of the PRC2 complex to an artificial promoter induces transcriptional repression and suggests that PcGs "by default" act as transcriptional repressors (Pasini et al. 2008). However, as discussed previously, PcGs also associate with promoters that are actively transcribed, suggesting that PcG-mediated transcriptional regulation is a complex process that likely involves different mechanisms and factors. If we only consider the repressive activity of the PRC complexes, it is not fully understood how PcG recruitment can negatively influence transcription. First of all, it has not been formally established that the catalytic activity and therefore the H3K27me3 mark are required for PRC2 function. Results from several laboratories, including ours, have shown that the growth-promoting and oncogenic effects of EZH2 depend on the presence of a functional SET domain (Bracken et al. 2003; Kleer et al. 2003). This suggests that K27 methylation is essential for PcG activity, but the fact that these studies are based on the use of a truncated form of EZH2 still leaves the question open. Mechanistically, it has been proposed that H3K27me 3 serves as a docking site for PRC1 recruitment and that this leads to ubiquitylation of H2AK119 and to compaction of chromatin (Francis et al. 2004; Cao et al. 
2005). These observations may suggest that PRC complexes repress transcription by preventing the binding of FACT, thereby leading to a block of RNA-polymeraseII-dependent elongation (Zhou et al. 2008).

The physiological role of $\mathrm{H} 3 \mathrm{~K} 27 \mathrm{me} 3$ in recruiting the PRC1 complex is also not fully understood. Even though $\mathrm{PRC} 2$ is required for the recruitment and maintenance of PRC1 on promoters (Cao et al. 2005; Boyer et al. 2006; Pasini et al. 2007), biochemical studies have shown that chromodomains of CBX proteins, which are part of different PRC1 complexes, have relatively low binding affinity for methylated lysines $\left(K_{\mathrm{d}}\right.$ in a higher micromolar range) and, in addition, do not appear to discriminate between $\mathrm{H} 3 \mathrm{~K} 9$ and $\mathrm{H} 3 \mathrm{~K} 27$ trimethylation (Bernstein et al. 2006b). Thus, although these studies have been performed in vitro, they suggest that binding of CBX proteins to trimethyl lysines is unlikely to be the only mechanism by which PRC1 complexes are recruited to target genes. In agreement with this interpretation is the demonstration that the swap of chromodomains between HP1 and Pc is not sufficient to completely relocalize these proteins to other genes/structures in the cell (Platero et al. 1995). Taken together, these results suggest that the PRC1 complexes contain domains other than the chromodomains of the CBX proteins that are essential for their recruitment to $\mathrm{PcG}$ target genes.

Once PRC1 is recruited to its target gene, it is believed to maintain transcriptional repression. The question is how this is achieved. The PRC1 complex contains two different enzymatic activities. RING1B catalyzes the ubiquitylation of H2AK119 (Wang et al. 2004), whereas CBX4 contains E3 SUMO ligase activity (Kagey et al. 2003). How these two activities are related to the ability of PRC1 to repress transcription is currently unknown. However, the PRC1 complex has the ability to compact nucleosomes in vitro, suggesting that the complex could create a less-accessible chromatin environment at target genes (Francis et al. 2004). It is possible that such an effect will exclude RNA polymerase II from PcG target genes, but the fact that PcG binding in Drosophila does not exclude RNA polymerase II association to some promoters (Breiling et al. 2001) and that $23 \%$ of Suz12 target genes in hES cells have polymerase II associated with their promoter (Lee et al. 2006) does not support such a mechanism.

In this connection, it is important to note that loss of PcG activity only leads to the transcriptional activation of a small subset of target genes (Boyer et al. 2006; Bracken et al. 2006; Lee et al. 2006). Moreover, this activation is relatively low when compared with the expression levels that are achieved during normal activation of PcG target genes. An example of this is illustrated in Figure 3A. Here, the expression levels of Gata4 and Tbxl are shown to be significantly higher during ES cell differentiation compared to their expression levels in Suz $12^{-/-}$ES cells. These observations suggest that PcG displacement from promoters during differentiation is required, but not sufficient, for efficient activation of transcription and propose that in ES cells, the transcription factors required for this activation are either not expressed or their recruitment is impaired by a PcG-independent mechanism. This inter- pretation is further supported by genome-wide studies (summarized in Fig. 3B-D) showing that a large proportion of PcG target genes present higher transcript levels during differentiation when compared to loss of PcG activity. The existence of different layers of transcriptional regulators to control the expression of the same gene is in agreement with the complex spatial and temporal transcription network that must be established to regulate proper development of an organism.

\section{HISTONE METHYLATION AND DEMETHYLATION}

The recent discovery of lysine demethylases (KDM) that can actively remove methylation groups from lysine residues has increased the complexity of transcriptional regulation even further. Until the discovery of LSD1, histone lysine methylation was believed to be a stable mark that could only be lost during DNA replication and/or by histone replacement. LSD1 can catalyze the demethylation of me1 and me 2 groups but not me 3 groups (Shi et al. 2004). For this reason, me 3 groups were considered a stable modification until the recent discovery that Jumonji $\mathrm{C}$ domain (JmjC)-containing proteins can actively remove me3 groups. This includes KDMs specific for H3K9me3/me2/me1, H3K36me3/me2, H3K27me3/me2, and $\mathrm{H} 3 \mathrm{~K} 4 \mathrm{me} 3 / \mathrm{me} 2$. Several of these KDMs are important for transcriptional regulation and are involved in different physiological processes, including differentiation and development (Agger et al. 2008; Cloos et al. 2008). For example, Jmjd1a (H3K9me $2 /$ me1-specific) and Jmjd2c (H3K9me3/me3- and H3K36me3/me2-specific) have been reported to be required for the pluripotency of mouse ES cells, potentially involving a mechanism removing $\mathrm{H} 3 \mathrm{~K} 9 \mathrm{me} 3$ from the Oct4 promoter and thereby preventing its transcriptional repression (Loh et al. 2007).

We and other investigators have shown that members of the JARID1 family specifically catalyze the demethylation of $\mathrm{H} 3 \mathrm{~K} 4 \mathrm{me} 3 / \mathrm{me} 2$ and that they are important for normal development (Christensen et al. 2007; Iwase et al. 2007; Klose et al. 2007; Lee et al. 2007a; Yamane et al. 2007). Recently, we have addressed the functional role of one member of the Jarid1 family (Rbp2/Jarid1a) in mouse ES cells (Pasini et al. 2008). By promoter location analysis, we have shown that Rbp2 is bound at the promoter of a large number of differentiation-related genes, suggesting that this activity may be involved in the repression of these genes in ES cells. In addition, we have demonstrated that Rbp2 and the PRC2 complex have a large number of common target genes, that Rbp2 and PRC2 interact, and that Rbp2 is required for the maintenance of the repression of $\mathrm{PcG}$ target genes (Pasini et al. 2008). These results show that the coordinated regulation of histone modifications by a repressive complex, containing KMT and KDM activities, may be important for the transcriptional regulation of different genes during differentiation and development. Interestingly, similar biochemical structures containing KMT and KDM activities have also been reported for the TrxG-like MLL complex, where the MLL2 and ASH2 H3K4me3 KMTs are associated in a complex containing 


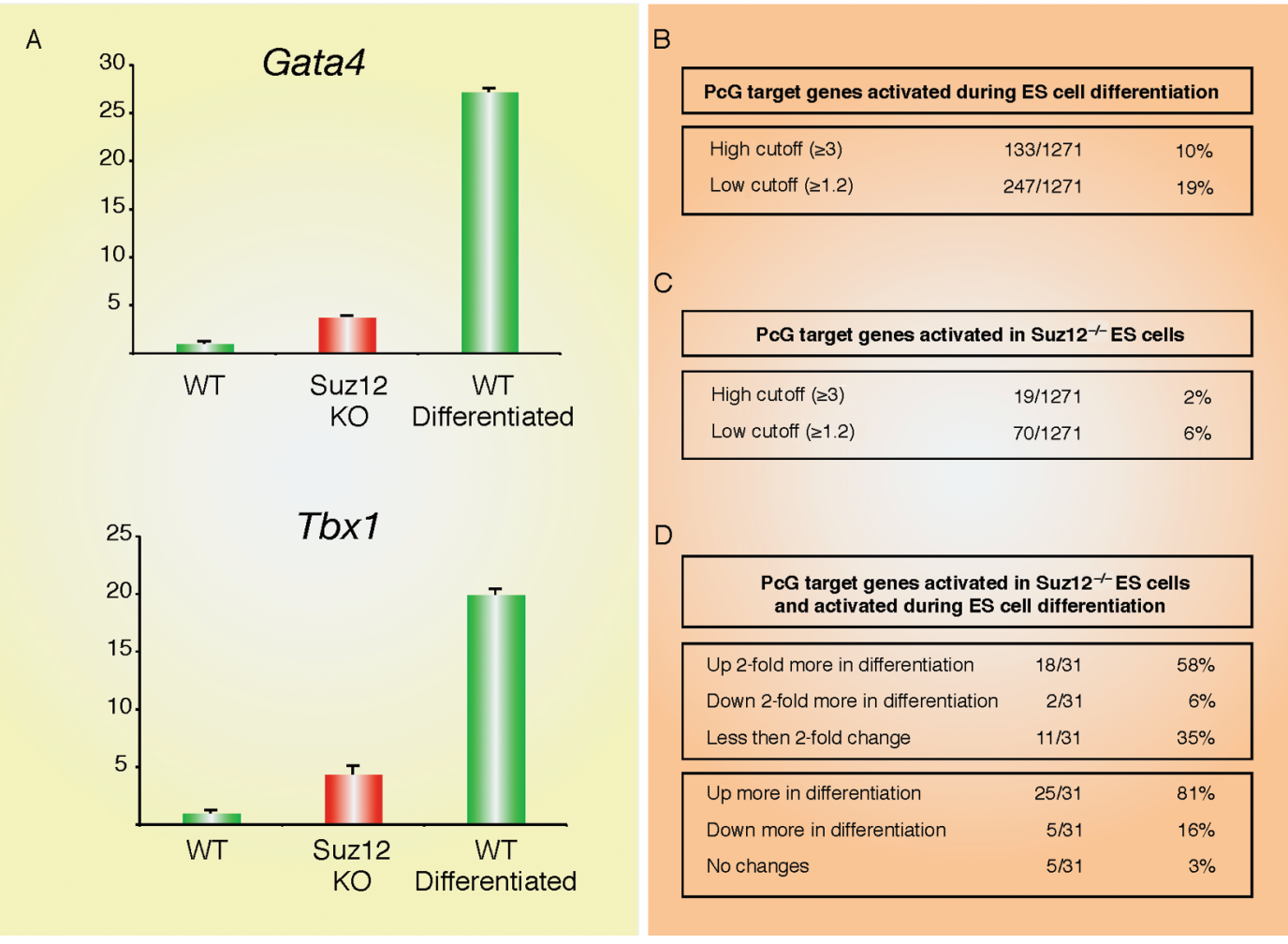

Figure 3. Different activities are required for the transcriptional regulation of PcG target genes during differentiation. (A) Gata4 and Tbx transcription in wild-type, Suz12 ${ }^{--}$, and differentiated wild-type mouse ES cells, showing that loss of PcG activity in ES cells is not sufficient for obtaining the full transcriptional activation achieved during ES cell differentiation (Pasini et al. 2007; D. Pasini, unpubl.). (B) Summary table obtained from genome-wide studies (Boyer et al. 2006; Lee et al. 2006), showing the proportion of PcG target genes that undergo transcriptional activation during mouse ES cell differentiation. $(C)$ Summary table obtained from genome-wide studies (Boyer et al. 2006; Lee et al. 2006) showing the proportion of PcG target genes that undergo transcriptional activation in Suz12 ${ }^{-/}$ES cells. $(D)$ Summary table obtained from genome-wide studies (Boyer et al. 2006; Lee et al. 2006), showing the proportion of PcG target genes that undergo transcriptional activation during mouse ES cell differentiation and in Suz12- $E S$ cells. Similar to the data presented in $A$, this table shows that a large proportion of PcG target genes that are activated during differentiation and in Suz $12^{-/-}$ES cells present higher transcript levels during differentiation relative to loss of Suz12 activity (58\% with a stringent cutoff or $81 \%$ with a low cutoff). "Up 2-fold more in differentiation" includes genes that have a twofold higher expression level during differentiation versus Suz $12^{-1}$ ES cells. "Down 2-fold more in differentiation" includes genes that have a twofold lower expression level during differentiation relative to Suz12 $2^{-1}$ ES cells. "Less than 2-fold change" includes genes with expression changes lower than twofold during differentiation relative to Suz12 $2^{-1-}$ ES cells. "Up more in differentiation" includes genes that have a higher expression level during differentiation relative to Suz12-- ES cells. "Down more in differentiation" includes genes that have a lower expression level during differentiation relative to Suz $12^{-/}$ES cells. "No changes" includes genes that have no expression changes during differentiation relative to Suz $12^{-/}$ES cells.

the H3K27me3-specific demethylase UTX (Agger et al. 2007; Issaeva et al. 2007; Lee et al. 2007b). These findings indicate that these different enzymatic activities function together to coordinately regulate lysine methylation and transcription. Moreover, they suggest that antagonistic activities act reciprocally during differentiation to regulate the "on" and "off" state of gene expression (Fig. 4).

\section{BIVALENT DOMAINS: AN ES CELL FEATURE?}

Recent studies using genome-wide tiling ChIP-chip and ChIP-seq approaches for different methylated residues of histone tails have identified a modification pattern in ES cells termed "bivalent domains," consisting of $\mathrm{H} 3 \mathrm{~K} 4 \mathrm{me} 3$ and $\mathrm{H} 3 \mathrm{~K} 27 \mathrm{me} 3$ on the same nucleosomes (Bernstein et al. 2006a). Despite the considerable number of H3K4me3-positive promoters in ES cells (78\% of total annotated promoters), a large proportion of H3K27me3-positive promoters are also H3K4me3-positive (96\% of Suz12 promoters) (Mikkelsen et al. 2007). This correlation is statistically significant (probability value $=1.4 \mathrm{E}^{-18}$ ), suggesting a functional role for the coexistence on these modifications. Interestingly, bivalent promoters correlate with low levels of expression, and bivalent domains are often lost in committed lineages (Mikkelsen et al. 2007; Mohn et al. 2008). Maintenance of H3K4me3, but not H3K27me3, correlates with activation of expression of bivalent genes in committed cell lines, suggesting that bivalency in ES cells has the function to maintain genes in a poised state for activation (Mikkelsen et al. 2007). This observation is extremely interesting and agrees with the transcriptional plasticity of pluripotent ES cells. Despite this, different questions in this regard remain unanswered. For 

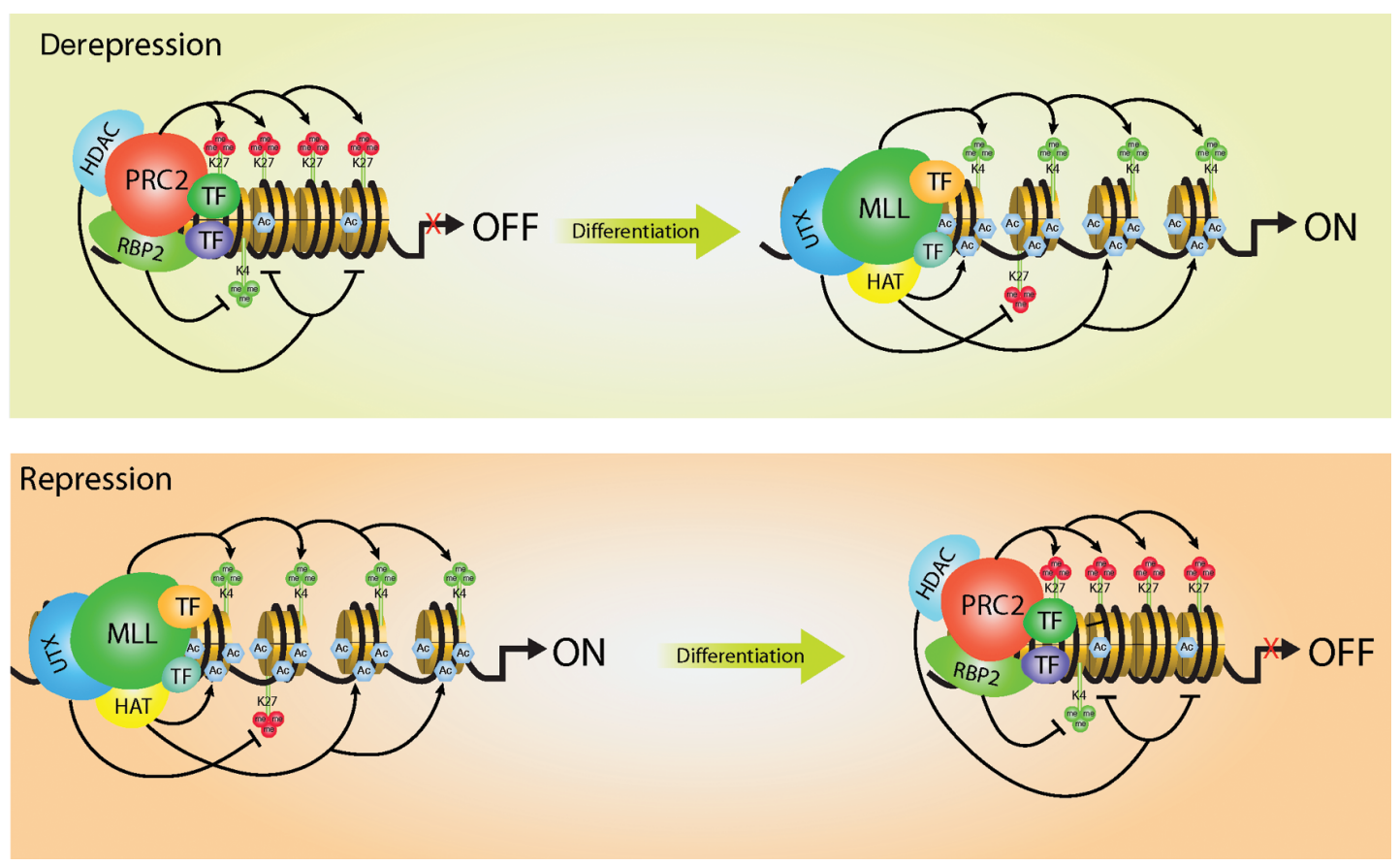

Figure 4. A model for the coordinated regulation of transcription by histone methyltransferases and demethylases during differentiation. The model highlights the antagonistic recruitment of repressive and activator complexes to regulate transcription during differentiation. The activator and repressive complexes contain opposite enzymatic activities. The repressive complex is formed by PRC2 H3K27 KMT activity, RBP2 H3K4 KDM activity, and HDAC de-acetylase activity, whereas the activator complex is formed by MLL H3K4 KMT activity, UTX H3K27 KDM activity, and HAT acetyltransferase activity. Furthermore, the model stresses that recruitment of the complexes could be mediated by multiple uncharacterized transcription factors.

example, is the bivalent mark important for transcriptional activation? What is the relevance for the bivalent mark at the CpG-rich promoter (HCG) if they are virtually all H3K4me3 (Mikkelsen et al. 2007)? Moreover, Bernstein and colleagues have suggested that most bivalent genes in ES cells resolve in committed cells, suggesting that bivalency is a specific feature of ES cells; however, recent data have shown that together with a proportion of genes that lose bivalency, there is a similar proportion of genes that gain bivalency during different stages of ES cell differentiation, demonstrating that bivalency is a feature not only of ES cells, but also of different committed cells types (Mohn et al. 2008). Additional work is required to better address the role of bivalent domains in regulating transcription during development.

The presence of bivalent domains may seem to be in contrast with our findings that $\mathrm{PcG}$ proteins coexist on a large number of $\mathrm{PcG}$ target genes with the $\mathrm{H} 3 \mathrm{~K} 4$ demethylase Rbp2 (Pasini et al. 2008). However, the association of Rbp2 with promoters does not appear to "erase" H3K4me3 from promoters but likely associates with the PRC2 complex to "fine-tune" the levels of $\mathrm{H} 3 \mathrm{~K} 4 \mathrm{me} 3$ at TSS. Loss of Rbp2 activity leads to increased $\mathrm{H} 3 \mathrm{~K} 4 \mathrm{me} 3$ levels, induces transcriptional activation, but does not affect PRC2 binding or H3K27me3 levels (Pasini et al. 2008). This interpretation is further supported by data that the H3K27me3 demethylase UTX is associated with promoters that are trimethylated on histone H3K27 (Agger et al. 2007; Lee et al. 2007b).

\section{PCGS AND DNA METHYLATION}

The methylation of a DNA cytosine residue within a $\mathrm{CpG}$ dinucleotide is an important mechanism for inherited epigenetic silencing of gene expression. $\mathrm{CpG}$ dinucleotides are found all over the genome, but they accumulate with high frequency in the proximity of TSS. These clusters of CpGs are defined as $\mathrm{CpG}$ islands. The hypermethylation of $\mathrm{CpG}$ islands leads to transcriptional repression (Bird 2002). DNA methylation is believed to be a stable modification that is inherited through many cell divisions, even a lifetime in the case of the inactivated $\mathrm{X}$ chromosome. In agreement with this, DNA methylation is faithfully inherited during DNA replication, and no bona fide DNA demethylase has so far been identified.

Recent data have shown that very few $\mathrm{CpG}$ islands are methylated in ES cells (Meissner et al. 2008). This is not surprising, because ES cells can differentiate into many different cell types and therefore require high transcriptional flexibility. Because DNA methylation is a stable modification, it will restrict the developmental potential of ES cells. In contrast, in terminally differentiated cells, which require low levels of plasticity and hence a stable expression program, many promoters are DNA-methylated. This DNA methylation, which is essential for differentiation, is acquired during the differentation process. The enzymes that catalyze DNA methylation belong to the DNMT protein family (Bird 2002). Recently, it was shown that PcG proteins are able to interact with all members of the DNMT family, and it was suggested that PcGs and DNMTs are dependent 
on each other for their recruitment to target promoters (Vire et al. 2006). These results are also interesting in the perspective of tumor development. Promoter DNA hypermethylation frequently silences tumor suppressor genes, whereas members of the PRC2 complex are overexpressed in many human tumors. Taken together, these findings suggest a mechanism that links PcG overexpression to promoter hypermethylation in the development of human cancer. However, the mechanism by which PcGs set up and maintain DNA methylation is still under debate because other publications have suggested that RNAi-based PcG depletion does not reactivate the expression of fully methylated genes (McGarvey et al. 2007) and that trimethylation of histone $\mathrm{H} 3 \mathrm{~K} 27$ is an alternative mechanism for repressing tumor suppressor genes in prostate cancer, which does not require DNA methylation (Kondo et al. 2008). Nevertheless, genome-wide studies in primary and cancer cell lines have shown that there is a significant correlation between being a PcG- and H3K27me3-enriched gene in ES cells and differentiated cells and becoming DNA-hypermethylated in cancer cells (Schlesinger et al. 2007; Widschwendter et al. 2007; Mohn et al. 2008). Moreover, consistent with an essential role of PcGs to repress genes instructive for cell-fate decisions, recent results have demonstrated that low expression of PcG target genes contributes significantly to an embryonic stem-cell-like gene expression signature in poorly differentiated aggressive human tumors (Ohm et al. 2007).

\section{CONCLUDING REMARKS}

In this symposium review, we have summarized the recent advances in understanding how histone methylation regulates pluripotency. In particular, we have focused on the role of Polycomb group proteins in regulating transcription during development. We have discussed several models by which they control gene expression, how they are recruited to their sites of action, and a number of other unresolved questions that will be extremely interesting to address in the future. This is an exciting field that moves very quickly, and we expect that many of the questions we have posed will be solved within the next few years.

\section{ACKNOWLEDGMENTS}

We thank members of the Helin lab for discussions. D.P. was supported by a postdoctoral fellowship from the Danish Medical Research Council and P.A.C.C. by a grant from the Benzon Foundation. The work in the Helin lab was supported by grants from the Danish Cancer Society, the Danish National Research Foundation, the Novo Nordisk Foundation, the Lundbeck Foundation, the Danish Medical Research Council, the Danish Natural Science Research Council, the International Association for Cancer Research, and the European Union.

\section{REFERENCES}

Agger, K., Cloos, P.A., Christensen, J., Pasini, D., Rose, S., Rappsilber, J., Issaeva, I., Canaani, E., Salcini, A.E., and Helin, K. 2007. UTX and JMJD3 are histone H3K27 demethylases involved in $H O X$ gene regulation and development. Nature 449: 731-734.

Agger, K., Christensen, J., Cloos, P.A., and Helin, K. 2008. The emerging functions of histone demethylases. Curr. Opin. Genet. Dev. 18: 159-168.

Bernstein, B.E., Mikkelsen, T.S., Xie, X., Kamal, M., Huebert, D.J., Cuff, J., Fry, B., Meissner, A., Wernig, M., Plath, K., et al. 2006a. A bivalent chromatin structure marks key developmental genes in embryonic stem cells. Cell 125: 315-326.

Bernstein, E., Duncan, E.M., Masui, O., Gil, J., Heard, E., and Allis, C.D. 2006b. Mouse polycomb proteins bind differentially to methylated histone $\mathrm{H} 3$ and RNA and are enriched in facultative heterochromatin. Mol. Cell. Biol. 26: 2560-2569.

Bird, A. 2002. DNA methylation patterns and epigenetic memory. Genes Dev. 16: 6-21.

Boyer, L.A., Plath, K., Zeitlinger, J., Brambrink, T., Medeiros, L.A., Lee, T.I., Levine, S.S., Wernig, M., Tajonar, A., Ray, M.K., et al. 2006. Polycomb complexes repress developmental regulators in murine embryonic stem cells. Nature 441: 349-353.

Bracken, A.P., Pasini, D., Capra, M., Prosperini, E., Colli, E., and Helin, K. 2003. EZH2 is downstream of the pRB-E2F pathway, essential for proliferation and amplified in cancer. EMBO J. 22: 5323-5335.

Bracken, A.P., Dietrich, N., Pasini, D., Hansen, K.H., and Helin, K. 2006. Genome-wide mapping of Polycomb target genes unravels their roles in cell fate transitions. Genes Dev. 20: 1123-1136.

Bracken, A.P., Kleine-Kohlbrecher, D., Dietrich, N., Pasini, D., Gargiulo, G., Beekman, C., Theilgaard-Monch, K., Minucci, S., Porse, B.T., Marine, J.C., et al. 2007. The Polycomb group proteins bind throughout the INK4A-ARF locus and are disassociated in senescent cells. Genes Dev. 21: 525-530.

Breiling, A., Turner, B.M., Bianchi, M.E., and Orlando, V. 2001. General transcription factors bind promoters repressed by Polycomb group proteins. Nature 412: 651-655.

Bresnick, E.H., Martowicz, M.L., Pal, S., and Johnson, K.D. 2005. Developmental control via GATA factor interplay at chromatin domains. J. Cell. Physiol. 205: 1-9.

Brock, H.W. and Fisher, C.L. 2005. Maintenance of gene expression patterns. Dev. Dyn. 232: 633-655.

Brown, J.L., Mucci, D., Whiteley, M., Dirksen, M.L., and Kassis, J.A. 1998. The Drosophila Polycomb group gene pleiohomeotic encodes a DNA binding protein with homology to the transcription factor YY1. Mol. Cell 1: 1057-1064.

Brown, J.L., Fritsch, C., Mueller, J., and Kassis, J.A. 2003. The Drosophila pho-like gene encodes a YY1-related DNA binding protein that is redundant with pleiohomeotic in homeotic gene silencing. Development 130: 285-294.

Bruggeman, S.W., Valk-Lingbeek, M.E., van der Stoop, P.P., Jacobs, J.J., Kieboom, K., Tanger, E., Hulsman, D., Leung, C., Arsenijevic, Y., Marino, S., and van Lohuizen, M. 2005. Ink4a and Arf differentially affect cell proliferation and neural stem cell self-renewal in Bmil-deficient mice. Genes Dev. 19: $1438-1443$.

Cao, R. and Zhang, Y. 2004. SUZ12 is required for both the histone methyltransferase activity and the silencing function of the EED-EZH2 complex. Mol. Cell 15: 57-67.

Cao, R., Wang, L., Wang, H., Xia, L., Erdjument-Bromage, H., Tempst, P., Jones, R.S., and Zhang, Y. 2002. Role of histone H3 lysine 27 methylation in Polycomb-group silencing. Science 298: 1039-1043.

Cao, R., Tsukada, Y., and Zhang, Y. 2005. Role of Bmi-1 and Ring1A in H2A ubiquitylation and Hox gene silencing. Mol. Cell 20: $845-854$

Caretti, G., Di Padova, M., Micales, B., Lyons, G.E., and Sartorelli, V. 2004. The Polycomb Ezh2 methyltransferase regulates muscle gene expression and skeletal muscle differentiation. Genes Dev. 18: 2627-2638.

Carlsson, P. and Mahlapuu, M. 2002. Forkhead transcription factors: Key players in development and metabolism. Dev. Biol. 250: 1-23.

Chamberlain, S.J., Yee, D., and Magnuson, T. 2008. Polycomb repressive complex 2 is dispensable for maintenance of embryonic stem cell pluripotency. Stem Cells 26: 1496 1505.

Christensen, J., Agger, K., Cloos, P.A., Pasini, D., Rose, S., Sennels, L., Rappsilber, J., Hansen, K.H., Salcini, A.E., and Helin, K. 2007. RBP2 belongs to a family of demethylases, 
specific for tri- and dimethylated lysine 4 on histone 3. Cell 128: $1063-1076$.

Cloos, P.A., Christensen, J., Agger, K., and Helin, K. 2008. Erasing the methyl mark: Histone demethylases at the center of cellular differentiation and disease. Genes Dev. 22: $1115-1140$.

Cohen, E.D., Tian, Y., and Morrisey, E.E. 2008. Wnt signaling: An essential regulator of cardiovascular differentiation, morphogenesis and progenitor self-renewal. Development 135: 789-798.

Czermin, B., Melfi, R., McCabe, D., Seitz, V., Imhof, A., and Pirrotta, V. 2002. Drosophila enhancer of Zeste/ESC complexes have a histone $\mathrm{H} 3$ methyltransferase activity that marks chromosomal Polycomb sites. Cell 111: 185-196.

de Napoles, M., Mermoud, J.E., Wakao, R., Tang, Y.A., Endoh, M., Appanah, R., Nesterova, T.B., Silva, J., Otte, A.P., Vidal, M., et al. 2004. Polycomb group proteins Ring1 A/B link ubiquitylation of histone $\mathrm{H} 2 \mathrm{~A}$ to heritable gene silencing and $\mathrm{X}$ inactivation. Dev. Cell 7: 663-676.

Dietrich, N., Bracken, A.P., Trinh, E., Schjerling, C.K., Koseki, H., Rappsilber, J., Helin, K., and Hansen, K.H. 2007. Bypass of senescence by the polycomb group protein $\mathrm{CBX} 8$ through direct binding to the INK4A-ARF locus. EMBO J. 26: 1637-1648.

Donohoe, M.E., Zhang, X., McGinnis, L., Biggers, J., Li, E., and Shi, Y. 1999. Targeted disruption of mouse Yin Yang 1 transcription factor results in peri-implantation lethality. Mol. Cell. Biol. 19: 7237-7244.

Endoh, M., Endo, T.A., Endoh, T., Fujimura, Y., Ohara, O., Toyoda, T., Otte, A.P., Okano, M., Brockdorff, N., Vidal, M., and Koseki, H. 2008. Polycomb group proteins Ring1A/B are functionally linked to the core transcriptional regulatory circuitry to maintain ES cell identity. Development 135: $1513-1524$.

Erhardt, S., Su, I.H., Schneider, R., Barton, S., Bannister, A.J., Perez-Burgos, L., Jenuwein, T., Kouzarides, T., Tarakhovsky, A., and Surani, M.A. 2003. Consequences of the depletion of zygotic and embryonic enhancer of zeste 2 during preimplantation mouse development. Development 130: 4235-4248.

Francis, N.J. and Kingston, R.E. 2001. Mechanisms of transcriptional memory. Nat. Rev. Mol. Cell Biol. 2: 409-421.

Francis, N.J., Saurin, A.J., Shao, Z., and Kingston, R.E. 2001. Reconstitution of a functional core polycomb repressive complex. Mol. Cell 8: 545-556.

Francis, N.J., Kingston, R.E., and Woodcock, C.L. 2004. Chromatin compaction by a polycomb group protein complex. Science 306: 1574-1577.

Gil, J., Bernard, D., Martínez, D., and Beach, D. 2004. Polycomb CBX7 has a unifying role in cellular lifespan. Nat. Cell Biol. 6: $67-72$.

Hanahan, D. and Weinberg, R.A. 2000. The hallmarks of cancer. Cell 100: 57-70.

Hayward, P., Kalmar, T., and Martinez Arias, A. 2008. Wnt/Notch signalling and information processing during development. Development 135: 411-424.

Herranz, N., Pasini, D., Díaz, V.M., Francí, C., Gutierrez, A., Dave, N., Escrivà, M., Hernandez-Muñoz, I., Di Croce, L., Helin, K., et al. 2008. Polycomb complex 2 is required for Ecadherin repression by the Snaill transcription factor. Mol. Cell. Biol. 28: 4772-4781.

Issaeva, I., Zonis, Y., Rozovskaia, T., Orlovsky, K., Croce, C.M., Nakamura, T., Mazo, A., Eisenbach, L., and Canaani, E. 2007. Knockdown of ALR (MLL2) reveals ALR target genes and leads to alterations in cell adhesion and growth. Mol. Cell. Biol. 27: 1889-1903.

Itoh, N. and Ornitz, D.M. 2008. Functional evolutionary history of the mouse Fgf gene family. Dev. Dyn. 237: 18-27.

Iwase, S., Lan, F., Bayliss, P., de la Torre-Ubieta, L., Huarte, M., Qi, H.H., Whetstine, J.R., Bonni, A., Roberts, T.M., and Shi, Y. 2007. The X-linked mental retardation gene SMCX/JARIDIC defines a family of histone $\mathrm{H} 3$ lysine 4 demethylases. Cell 128: 1077-1088.

Jacobs, J.J., Kieboom, K., Marino, S., DePinho, R.A., and van Lohuizen, M. 1999. The oncogene and Polycomb-group gene bmi-1 regulates cell proliferation and senescence through the ink4a locus. Nature 397: 164-168.

Kagey, M.H., Melhuish, T.A., and Wotton, D. 2003. The polycomb protein Pc2 is a SUMO E3. Cell 113: 127-137.

Kagey, M.H., Melhuish, T.A., Powers, S.E., and Wotton, D. 2005. Multiple activities contribute to Pc2 E3 function. EMBO J. 24: 108-119.

Keller, G. 2005. Embryonic stem cell differentiation: Emergence of a new era in biology and medicine. Genes Dev. 19: $1129-1155$.

Kennison, J.A. 1995. The Polycomb and trithorax group proteins of Drosophila: Trans-regulators of homeotic gene function. Annu. Rev. Genet. 29: 289-303.

Kiefer, J.C. 2007. Back to basics: Sox genes. Dev. Dyn. 236: 2356-2366.

Kitisin, K., Saha, T., Blake, T., Golestaneh, N., Deng, M., Kim, C., Tang, Y., Shetty, K., Mishra, B., and Mishra, L. 2007. Tgf$\beta$ signaling in development. Sci. STKE 2007: $\mathrm{cm} 1$.

Kleer, C.G., Cao, Q., Varambally, S., Shen, R., Ota, I., Tomlins, S.A., Ghosh, D., Sewalt, R.G., Otte, A.P., Hayes, D.F., et al. 2003. EZH2 is a marker of aggressive breast cancer and promotes neoplastic transformation of breast epithelial cells. Proc. Natl. Acad. Sci. 100: 11606-11611.

Klose, R.J., Yan, Q., Tothova, Z., Yamane, K., ErdjumentBromage, H., Tempst, P., Gilliland, D.G., Zhang, Y., and Kaelin Jr., W.G. 2007. The retinoblastoma binding protein RBP2 is an H3K4 demethylase. Cell 128: 889-900.

Kondo, Y., Shen, L., Cheng, A.S., Ahmed, S., Boumber, Y., Charo, C., Yamochi, T., Urano, T., Furukawa, K., KwabiAddo, B., et al. 2008. Gene silencing in cancer by histone H3 lysine 27 trimethylation independent of promoter DNA methylation. Nat. Genet. 40: 741-750.

Kuzmichev, A., Nishioka, K., Erdjument-Bromage, H., Tempst, P., and Reinberg, D. 2002. Histone methyltransferase activity associated with a human multiprotein complex containing the Enhancer of Zeste protein. Genes Dev. 16: 2893-2905.

Kuzmichev, A., Jenuwein, T., Tempst, P., and Reinberg, D. 2004. Different ezh2-containing complexes target methylation of histone h1 or nucleosomal histone H3. Mol. Cell 14: 183-193.

Lang, D., Powell, S.K., Plummer, R.S., Young, K.P., and Ruggeri, B.A. 2007. PAX genes: Roles in development, pathophysiology, and cancer. Biochem. Pharmacol. 73: 1-14.

Laverriere, A.C., MacNeill, C., Mueller, C., Poelmann, R.E., Burch, J.B., and Evans, T. 1994. GATA-4/5/6, a subfamily of three transcription factors transcribed in developing heart and gut. J. Biol. Chem. 269: 23177-23184.

Lavigne, M., Francis, N.J., King, I.F., and Kingston, R.E. 2004. Propagation of silencing: Recruitment and repression of naive chromatin in trans by polycomb repressed chromatin. Mol. Cell 13: 415-425.

Lee, T.I., Jenner, R.G., Boyer, L.A., Guenther, M.G., Levine, S.S., Kumar, R.M., Chevalier, B., Johnstone, S.E., Cole, M.F., Isono, K., et al. 2006. Control of developmental regulators by Polycomb in human embryonic stem cells. Cell 125: 301-313.

Lee, M.G., Norman, J., Shilatifard, A., and Shiekhattar, R. 2007a. Physical and functional association of a trimethyl H3K4 demethylase and Ring6a/MBLR, a polycomb-like protein. Cell 128: 877-887.

Lee, M.G., Villa, R., Trojer, P., Norman, J., Yan, K.P., Reinberg, D., Di Croce, L., and Shiekhattar, R. 2007b. Demethylation of H3K27 regulates polycomb recruitment and H2A ubiquitination. Science 318: 447-450.

Loh, Y.H., Zhang, W., Chen, X., George, J., and Ng, H.H. 2007. Jmjd1a and Jmjd2c histone H3 Lys 9 demethylases regulate self-renewal in embryonic stem cells. Genes Dev. 21: 2545-2557.

Lowe, S.W. and Sherr, C.J. 2003. Tumor suppression by Ink4aArf: Progress and puzzles. Curr. Opin. Genet. Dev. 13: 77-83.

McGarvey, K.M., Greene, E., Fahrner, J.A., Jenuwein, T., and Baylin, S.B. 2007. DNA methylation and complete transcriptional silencing of cancer genes persist after depletion of EZH2. Cancer Res. 67: 5097-5102.

Meissner, A., Mikkelsen, T.S., Gu, H., Wernig, M., Hanna, J., Sivachenko, A., Zhang, X., Bernstein, B.E., Nusbaum, C., Jaffe, D.B., et al. 2008. Genome-scale DNA methylation 
maps of pluripotent and differentiated cells. Nature 454: 766-770.

Mikkelsen, T.S., Ku, M., Jaffe, D.B., Issac, B., Lieberman, E., Giannoukos, G., Alvarez, P., Brockman, W., Kim, T.K., Koche, R.P., et al. 2007. Genome-wide maps of chromatin state in pluripotent and lineage-committed cells. Nature 448: 553-560.

Mohn, F., Weber, M., Rebhan, M., Roloff, T.C., Richter, J., Stadler, M.B., Bibel, M., and Schubeler, D. 2008. Lineagespecific polycomb targets and de novo DNA methylation define restriction and potential of neuronal progenitors. $\mathrm{Mol}$. Cell 30: 755-766.

Molofsky, A.V., He, S., Bydon, M., Morrison, S.J., and Pardal, R. 2005. Bmi-1 promotes neural stem cell self-renewal and neural development but not mouse growth and survival by repressing the $\mathrm{p} 16^{\mathrm{Ink} 4 \mathrm{a}}$ and $\mathrm{p} 19^{\mathrm{Arf}}$ senescence pathways. Genes Dev. 19: 1432-1437.

Montgomery, N.D., Yee, D., Chen, A., Kalantry, S., Chamberlain, S.J., Otte, A.P., and Magnuson, T. 2005. The murine polycomb group protein Eed is required for global histone H3 lysine-27 methylation. Curr. Biol. 15: 942-947.

Müller, J., Hart, C.M., Francis, N.J., Vargas, M.L., Sengupta, A., Wild, B., Miller, E.L., O'Connor, M.B., Kingston, R.E., and Simon, J.A. 2002. Histone methyltransferase activity of a Drosophila Polycomb group repressor complex. Cell 111: 197-208.

O'Carroll, D., Erhardt, S., Pagani, M., Barton, S.C., Surani, M.A., and Jenuwein, T. 2001. The Polycomb-group gene Ezh2 is required for early mouse development. Mol. Cell. Biol. 21: 4330-4336.

Ohm, J.E., McGarvey, K.M., Yu, X., Cheng, L., Schuebel, K.E., Cope, L., Mohammad, H.P., Chen, W., Daniel, V.C., Yu, W., et al. 2007. A stem cell-like chromatin pattern may predispose tumor suppressor genes to DNA hypermethylation and heritable silencing. Nat. Genet. 39: 237-242.

Orlando, V., Jane, E.P., Chinwalla, V., Harte, P.J., and Paro, R. 1998. Binding of trithorax and Polycomb proteins to the bithorax complex: Dynamic changes during early Drosophila embryogenesis. EMBO J. 17: 5141-5150.

Pasini, D., Bracken, A.P., and Helin, K. 2004a. Polycomb group proteins in cell cycle progression and cancer. Cell Cycle 3: 396-400.

Pasini, D., Bracken, A.P., Jensen, M.R., Denchi, E.L., and Helin, K. 2004b. Suz12 is essential for mouse development and for EZH2 histone methyltransferase activity. EMBO J. 23: 4061-4071.

Pasini, D., Bracken, A.P., Hansen, J.B., Capillo, M., and Helin, K. 2007. The polycomb group protein Suz12 is required for embryonic stem cell differentiation. Mol. Cell. Biol. 27: 3769-3779.

Pasini, D., Hansen, K.H., Christensen, J., Agger, K., Cloos, P.A., and Helin, K. 2008. Coordinated regulation of transcriptional repression by the RBP2 H3K4 demethylase and PolycombRepressive Complex 2. Genes Dev. 22: 1345-1355.

Plageman, Jr., T.F. and Yutzey, K.E. 2005. T-box genes and heart development: Putting the "T" in heart. Dev. Dyn. 232: $11-20$.

Platero, J.S., Hartnett, T., and Eissenberg, J.C. 1995. Functional analysis of the chromo domain of HP1. EMBO J. 14: 3977-3986.

Puschendorf, M., Terranova, R., Boutsma, E., Mao, X., Isono, K., Brykczynska, U., Kolb, C., Otte, A.P., Koseki, H., Orkin, S.H., et al. 2008. PRC1 and Suv39h specify parental asymmetry at constitutive heterochromatin in early mouse embryos. Nat. Genet. 40: 411-420.

Riising, E.M., Boggio, R., Chiocca, S., Helin, K., and Pasini, D. 2008. The polycomb repressive complex 2 is a potential target of SUMO modifications. PLOS ONE 3: e2704.

Ringrose, L. and Paro, R. 2004. Epigenetic regulation of cellular memory by the Polycomb and Trithorax group proteins. Annu. Rev. Genet. 38: 413-443.

Ringrose, L. and Paro, R. 2007. Polycomb/Trithorax response elements and epigenetic memory of cell identity. Development 134: 223-232.

Ringrose, L., Rehmsmeier, M., Dura, J.M., and Paro, R. 2003.
Genome-wide prediction of Polycomb/Trithorax response elements in Drosophila melanogaster. Dev. Cell 5: 759-771.

Schlesinger, Y., Straussman, R., Keshet, I., Farkash, S., Hecht, M., Zimmerman, J., Eden, E., Yakhini, Z., Ben-Shushan, E., Reubinoff, B.E., et al. 2007. Polycomb-mediated methylation on Lys27 of histone $\mathrm{H} 3$ pre-marks genes for de novo methylation in cancer. Nat. Genet. 39: 232-236.

Sherr, C.J. 1998. Tumor surveillance via the ARF-p53 pathway. Genes Dev. 12: 2984-2991.

Shi, Y., Lan, F., Matson, C., Mulligan, P., Whetstine, J.R., Cole, P.A., Casero, R.A., and Shi, Y. 2004. Histone demethylation mediated by the nuclear amine oxidase homolog LSD1. Cell 119: 941-953.

Simon, J.A. and Tamkun, J.W. 2002. Programming off and on states in chromatin: Mechanisms of Polycomb and trithorax group complexes. Curr. Opin. Genet. Dev. 12: 210-218.

Squazzo, S.L., O'Geen, H., Komashko, V.M., Krig, S.R., Jin, V.X., Jang, S.W., Margueron, R., Reinberg, D., Green, R., and Farnham, P.J. 2006. Suz12 binds to silenced regions of the genome in a cell-type-specific manner. Genome Res. 16: 890-900.

Stock, J.K., Giadrossi, S., Casanova, M., Brookes, E., Vidal, M., Koseki, H., Brockdorff, N., Fisher, A.G., and Pombo, A. 2007. Ring1-mediated ubiquitination of $\mathrm{H} 2 \mathrm{~A}$ restrains poised RNA polymerase II at bivalent genes in mouse ES cells. Nat. Cell Biol. 9: 1428-1435.

Su, I.H., Basavaraj, A., Krutchinsky, A.N., Hobert, O., Ullrich, A., Chait, B.T., and Tarakhovsky, A. 2003. Ezh2 controls B cell development through histone $\mathrm{H} 3$ methylation and Igh rearrangement. Nat. Immunol. 4: 124-131.

Su, I.H., Dobenecker, M.W., Dickinson, E., Oser, M., Basavaraj, A., Marqueron, R., Viale, A., Reinberg, D., Wulfing, C., and Tarakhovsky, A. 2005. Polycomb group protein ezh 2 controls actin polymerization and cell signaling. Cell 121: 425-436.

van der Lugt, N.M., Domen, J., Linders, K., van Roon, M., Robanus-Maandag, E., te Riele, H., van der Valk, M., Deschamps, J., Sofroniew, M., van Lohuizen, M., et al. 1994. Posterior transformation, neurological abnormalities, and severe hematopoietic defects in mice with a targeted deletion of the bmi-1 proto-oncogene. Genes Dev. 8: 757-769.

van der Stoop, P., Boutsma, E.A., Hulsman, D., Noback, S., Heimerikx, M., Kerkhoven, R.M., Voncken, J.W., Wessels, L.F., and van Lohuizen, M. 2008. Ubiquitin E3 ligase Ring $1 \mathrm{~b} / \mathrm{Rnf} 2$ of polycomb repressive complex 1 contributes to stable maintenance of mouse embryonic stem cells. PLoS ONE 3: e2235.

Vire, E., Brenner, C., Deplus, R., Blanchon, L., Fraga, M., Didelot, C., Morey, L., Van Eynde, A., Bernard, D., Vanderwinden, J.M., et al. 2006. The Polycomb group protein EZH2 directly controls DNA methylation. Nature 439: 871-874.

Voncken, J.W., Roelen, B.A., Roefs, M., de Vries, S., Verhoeven, E., Marino, S., Deschamps, J., and van Lohuizen, M. 2003. Rnf2 (Ringlb) deficiency causes gastrulation arrest and cell cycle inhibition. Proc. Natl. Acad. Sci. 100: 2468-2473.

Wang, H., Wang, L., Erdjument-Bromage, H., Vidal, M., Tempst, P., Jones, R.S., and Zhang, Y. 2004. Role of histone H2A ubiquitination in Polycomb silencing. Nature 431: 873-878.

Wellik, D.M. 2007. Hox patterning of the vertebrate axial skeleton. Dev. Dyn. 236: 2454-2463.

Widschwendter, M., Fiegl, H., Egle, D., Mueller-Holzner, E., Spizzo, G., Marth, C., Weisenberger, D.J., Campan, M., Young, J., Jacobs, I., and Laird, P.W. 2007. Epigenetic stem cell signature in cancer. Nat. Genet. 39: 157-158.

Yamane, K., Tateishi, K., Klose, R.J., Fang, J., Fabrizio, L.A., Erdjument-Bromage, H., Taylor-Papadimitriou, J., Tempst, P., and Zhang, Y. 2007. PLU-1 is an H3K4 demethylase involved in transcriptional repression and breast cancer cell proliferation. Mol. Cell 25: 801-812.

Zhou, W., Zhu, P., Wang, J., Pascual, G., Ohgi, K.A., Lozach, J., Glass, C.K., and Rosenfeld, M.G. 2008. Histone H2A monoubiquitination represses transcription by inhibiting RNA polymerase II transcriptional elongation. Mol. Cell 29: 69-80. 


\section{$8_{\text {CSH\& }}^{\infty}$ Cold Spring Harbor Symposia SYMPOSIA on Quantitative Biology}

\section{Regulation of Stem Cell Differentiation by Histone Methyltransferases and Demethylases}

D. Pasini, A.P. Bracken, K. Agger, et al.

Cold Spring Harb Symp Quant Biol 2008 73: 253-263 originally published online November 6, 2008 Access the most recent version at doi:10.1101/sqb.2008.73.009

References This article cites 98 articles, 38 of which can be accessed free at: http://symposium.cshlp.org/content/73/253.full.html\#ref-list-1

License

Email Alerting Receive free email alerts when new articles cite this article - sign up in the Service box at the top right corner of the article or click here.

To subscribe to Cold Spring Harbor Symposia on Quantitative Biology go to: http://symposium.cshlp.org/subscriptions 